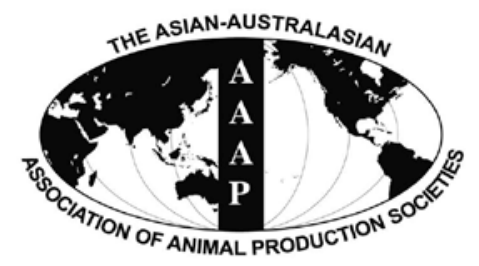

Asian-Aust. J. Anim. Sci.

Vol. 25, No. 2 : 234 - 239

February 2012

www.ajas.info

http://dx.doi.org/10.5713/ajas.2011.11242

\title{
The Effect of Forage Level and Oil Supplement on Butyrivibrio fibrisolvens and Anaerovibrio lipolytica in Continuous Culture Fermenters
}

\author{
P. Gudla, A. Ishlak and A. A. AbuGhazaleh* \\ Department of Animal Science, Food and Nutrition, Southern Illinois University Carbondale, IL 62901, USA
}

\begin{abstract}
The objective of this study was to evaluate the effects of forage level and oil supplement on selected strains of rumen bacteria believed to be involved in biohydrogenation $(\mathrm{BH})$. A continuous culture system consisting of four fermenters was used in a $4 \times 4$ Latin square design with a factorial arrangement of treatments, with four $10 \mathrm{~d}$ consecutive periods. Treatment diets were: i) high forage diet (70:30 forage to concentrate (dry matter basis); HFC), ii) high forage plus oil supplement (HFO), iii) low forage diet (30:70 forage to concentrate; LFC), and iv) low forage plus oil supplement (LFO). The oil supplement was a blend of fish oil and soybean oil added at 1 and $2 \mathrm{~g} / 100 \mathrm{~g}$ dry matter, respectively. Treatment diets were fed for 10 days and samples were collected from each fermenter on the last day of each period $3 \mathrm{~h}$ post morning feeding. The concentrations of vaccenic acid ( $t 11 \mathrm{C} 18: 1$; VA) and $c 9 t 11$ conjugated linoleic acid (CLA) were greater with the high forage diet while the concentrations of $t 10$ C18:1 and $t 10 c 12$ CLA were greater with the low forage diet and addition of oil supplement increased their concentrations at both forage levels. The DNA abundance of Anaerovibrio lipolytica, and Butyrivibrio fibrisolvens vaccenic acid subgroup (Butyrivibrio VA) were lower with the low forage diets but not affected by oil supplement. The DNA abundance of Butyrivibrio fibrisolvens stearic acid producer subgroup (Butyrivibrio SA) was not affected by forage level or oil supplement. In conclusion, oil supplement had no effects on the tested rumen bacteria and forage level affected Anaerovibrio lipolytica and Butyrivibrio VA. (Key Words : Oil, Forage Level, Biohydrogenation, Trans Fatty Acids, Fermenters)
\end{abstract}

\section{INTRODUCTION}

Trans C18:1 fatty acids (FA) and conjugated linoleic acid (CLA) are produced by the incomplete biohydrogenation $(\mathrm{BH})$ of long chain unsaturated FA in the rumen (Harfoot and Hazlewood, 1997), and are subsequently incorporated into milk and meat of ruminant animals. The different positional and geometric isomers of CLA confer different health effects on mammals (Bhattacharya et al., 2006; Kelly et al., 2007). The c9t11 CLA isomer has been shown to be anticarcinogenic (Amarù and Field, 2009; Huot et al., 2010), while the t10c12 CLA isomer has been shown capable of decreasing body fat and increasing lean body mass (Miranda et al., 2009; Jiang et al., 2010). The t10c12 CLA isomer also decreases fat concentration in dairy cow's milk in a dose dependent fashion (Peterson et al., 2002).

Formation of trans C18:1 FA and CLA in the rumen are

\footnotetext{
* Corresponding Author: Amer A. AbuGhazaleh. Tel: +1-618453-1767, Fax: +1-618-453-5231, E-mail: aabugha@siu.edu Received July 23, 2011; Accepted October 27, 2011
}

known to be influenced by dietary supplementation with unsaturated plant oils (Varadyova et al., 2007; Doreau et al., 2009; Duckett and Gillis, 2010), fish oil (Jin et al., 2008; Lee et al., 2008) or rumen pH (Sackmann et al., 2003; AbuGhazaleh and Jacobson, 2007; Alzahal et al., 2009). Feeding low forage diets supplemented with plant oils, fish oil or their blend (Loor et al., 2004; AbuGhazaleh and Jacobson, 2007; Belenguer et al., 2010) altered ruminal BH resulting in $t 10$ rather than VA being the predominant trans C18:1 intermediates. Similarly, Fuentes et al. (2009) showed that the flow of VA and c9t11 CLA from fermenters decreased while the flow of $t 10$ C18:1 and t10c12 CLA increased when high concentrate diet replaced high forage diet. Although the effects of lipid supplements and forage level on ruminal trans FA formation are well documented, little information is currently available about the effects of feeding such diets on rumen microbial ecology, particularly, bacterial species believed to be involved in the BH process.

Harfoot and Hazlewood (1997) categorized the bacteria involved in the different steps of the BH pathway into two groups. Group A bacteria hydrogenate linoleic acid 
Table 2. PCR primers and starting DNA concentration for detection of selected ruminal bacteria

\begin{tabular}{llccc}
\hline Target bacterium & \multicolumn{1}{c}{ Primer sequences (5'-3') } & $\begin{array}{r}\text { Starting DNA concentration } \\
(\mathrm{ng}) / 25 \mu \mathrm{l}\end{array}$ & $\begin{array}{c}\text { Annealing } \\
\text { temp }\left({ }^{\circ} \mathrm{C}\right)\end{array}$ & $\begin{array}{c}\text { Product size } \\
(\mathrm{bp})\end{array}$ \\
\hline Butyrivibrio SA & F: TCCGGTGGTATGAGATGGGC & 18 & 60 & 126 \\
Butyrivibrio VA & R: GTCGCTGCATCAGAGTTTCCT & & 60 & 124 \\
Anaerovibrio lipolytica & F: GCCTCAGCGTCAGTAATCG & 18 & 57 & 597 \\
& F: GGAGCGTAGGCGTTTTAC & & 60 & 57 \\
\hline
\end{tabular}

RNAse free water were added to make a total volume of 25 $\mu \mathrm{l}$. Amplifications for Anaerovibrio lipolytica and Butyrivibrio SA and Butyrivibrio VA were described by Potu et al. (2011) and Fuentes et al. (2009), respectively. Standard curves, DNA sample quantification and melting curve analyses were obtained using iQ5 Optical System Software (version 2.1, Bio-Rad laboratories, Inc, Hercules, CA, USA). Melting curve analysis was performed after each amplification step to determine the specificity of PCR product. Samples were amplified in triplicate along with dilution standards of known bacterial DNA concentrations. Samples and standards were assayed on the same plate to allow for the relative quantification of bacterial DNA present in sample.

\section{Statistical analysis}

Data were analyzed as a $4 \times 4$ Latin square design in a $2 \times$ 2 factorial design using the PROC MIXED of SAS (SAS Institute, Inc., Cary, NC). The statistical model included: forage effect, oil effect, and their interactions. Fixed effects were treatment diets and period. Random effect was fermenter. Results were expressed as least square means with standard error of the means. The significance threshold was set at $\mathrm{p}<0.05$. The statistical model was:

$$
\mathrm{Y}_{\mathrm{ijk}}=\mu+\mathrm{F}_{\mathrm{i}}+\mathrm{O}_{\mathrm{j}}+\mathrm{P}_{\mathrm{ij}}+\mathrm{e}_{\mathrm{ij}}
$$

where $Y_{i j k}=$ the observation; $\mu=$ overall mean; $F_{i}=$ forage effect (forage level; $\mathrm{HF}$ and $\mathrm{LF}$ ); $\mathrm{O}_{\mathrm{j}}=$ oil effect; $\mathrm{P}_{\mathrm{ij}}=$ forage and oil interaction and $\mathrm{e}_{\mathrm{ij}}=$ residual error.

\section{RESULTS AND DISCUSSION}

The fermenters $\mathrm{pH}$ for the high and low forage diets averaged 6.58 and 5.53, respectively and was not affected by oil supplement. The effects of forage level and oil supplement on selected $\mathrm{BH}$ intermediates are presented in Table 3. The greater concentration of trans C18:1 along with the lower concentration of C18:0 with the LFC relative to the HFC suggest an incomplete $\mathrm{BH}$ of unsaturated $\mathrm{FA}$ with the LFC. Low ruminal $\mathrm{pH}$, caused by a highconcentrate diet, increased the accumulation of trans C18:1 in other studies (Piperova et al., 2002; Loor et al., 2004; AbuGhazaleh and Jacobson, 2007). Although the cause of the accumulation of trans C18:1 under low rumen $\mathrm{pH}$ conditions is still unknown, alteration of the rumen

Table 3. The effect of forage level and oil supplements on fermenter fatty acid (mg/g DM)

\begin{tabular}{|c|c|c|c|c|c|c|c|c|}
\hline \multirow{2}{*}{ Fatty acid } & \multicolumn{4}{|c|}{ Treatment } & \multirow{2}{*}{ MSE } & \multicolumn{3}{|c|}{$\mathrm{p}$ value } \\
\hline & $\mathrm{HFC}^{\mathrm{a}}$ & $\mathrm{HFO}^{\mathrm{b}}$ & $\mathrm{LFC}^{\mathrm{C}}$ & $\mathrm{LFO}^{\mathrm{d}}$ & & Forage & Oil & Forage $\times$ oil \\
\hline C18:0 & 9.47 & 3.81 & 0.98 & 3.03 & 0.612 & 0.01 & 0.02 & 0.01 \\
\hline C18:1 total trans & 2.75 & 17.71 & 5.63 & 12.33 & 0.887 & 0.20 & 0.07 & 0.57 \\
\hline$t 10$ C18:1 & 0.24 & 0.79 & 5.08 & 9.09 & 0.462 & 0.01 & 0.01 & 0.01 \\
\hline$t 11 \mathrm{C} 18: 1(\mathrm{VA})^{\mathrm{e}}$ & 2.05 & 15.78 & 0.41 & 2.02 & 0.886 & 0.01 & 0.01 & 0.01 \\
\hline C18:1n9 & 1.99 & 5.14 & 7.15 & 7.08 & 1.012 & 0.01 & 0.18 & 0.17 \\
\hline C18:2n6 & 2.43 & 4.56 & 7.07 & 10.67 & 0.559 & 0.01 & 0.01 & 0.24 \\
\hline C18:3n3 & 0.84 & 1.12 & 0.81 & 1.26 & 0.101 & 0.61 & 0.01 & 0.44 \\
\hline$c 9 \mathrm{t} 11 \mathrm{CLA}^{\mathrm{f}}$ & 0.18 & 0.58 & $\mathrm{nd}^{\mathrm{g}}$ & 0.06 & 0.054 & 0.01 & 0.01 & 0.01 \\
\hline$t 10 c 12$ CLA & nd & 0.02 & 0.09 & 0.48 & 0.061 & 0.01 & 0.01 & 0.02 \\
\hline
\end{tabular}

${ }^{\mathrm{a}} \mathrm{HFC}=$ High forage control diet; alfalfa pellets at $700 \mathrm{~g} / \mathrm{kg}$ (diet DM) and no oil supplementation.

${ }^{\mathrm{b}} \mathrm{HFO}=$ High forage oil diet; control diet with $20 \mathrm{~g} / \mathrm{kg}$ (diet DM) soybean oil and $10 \mathrm{~g} / \mathrm{kg}$ (diet DM) fish oil.

${ }^{\mathrm{c}} \mathrm{LFC}=$ Low forage control diet; alfalfa pellets at $300 \mathrm{~g} / \mathrm{kg}$ (diet DM) and no oil supplementation.

${ }^{\mathrm{d}}$ LFO = Low forage oil diet; control diet with $20 \mathrm{~g} / \mathrm{kg}$ (diet DM) soybean oil and $10 \mathrm{~g} / \mathrm{kg}$ (diet DM) fish oil.

${ }^{\mathrm{e}} \mathrm{VA}=$ Vaccenic acid. ${ }^{\mathrm{f}} \mathrm{CLA}=$ Conjugated linoleic acid. ${ }^{\mathrm{g}}$ nd $=$ Not detected . 
ecosystem and/or inhibition of the reductase activity of ruminal microorganisms responsible for the reduction of trans C18:1 to C18:0 have been suggested (Loor et al., 2004; AbuGhazaleh and Jacobson, 2007). Despite the greater concentration of trans C18:1 with the LFC diet, the greater concentrations of $\mathrm{BH}$ products (the sum of trans C18:1 and C18:0) seen with the HFC (12.22 mg/g of DM) compared with the LFC (6.61 mg/g of DM) suggest greater microbial $\mathrm{BH}$ activities with the high forage diets. The increase in the concentration of trans C18:1 with oil supplement was expected as inputs of dietary C18 unsaturated FA, the precursors for trans C18:1, were increased with the oil supplement. Other studies also reported similar increases in trans C18:1 concentration in rumen (Varadyova et al., 2007; Belenguer et al., 2010) and duodenum (Kucuk et al., 2008) when oils were included in the diets of ruminant animals. The greater increase in trans C18:1 concentration with oils addition to the high forage diet further support the findings that greater $\mathrm{BH}$ activities occurred in fermenters fed the high forage diets (discussed below).

The concentration of VA was greater $(\mathrm{p}<0.05)$ with the high forage diets while the concentration of $t 10$ C18:1 was greater $(\mathrm{p}<0.05)$ with the low forage diets and both increased $(\mathrm{p}<0.05)$ further with oil supplementation (Table 3). Similarly, the concentration of c9t11 CLA was greater $(\mathrm{p}<0.05)$ with the high forage diets while the concentration of $t 10 c 12$ CLA was greater $(\mathrm{p}<0.05)$ with the low forage diets and both increased $(\mathrm{p}<0.05)$ further with oil supplementation. The lower concentrations of VA and $c 9 t 11$ CLA with the low forage diet are consistent with previous studies that showed a shift toward $t 10 \mathrm{C} 18: 1$ and $t 10 c 12$ CLA formation with decreasing dietary forage level (Piperova et al., 2002; Sackmann et al., 2003; AbuGhazaleh and Jacobson, 2007) or low ruminal pH (Choi et al., 2005; Fuentes et al., 2009). At a constant dietary oil level, AbuGhazaleh and Jacobson (2007) showed that decreasing dietary forage levels resulted in $t 10 \mathrm{C} 18: 1$ and $t 10 c 12$ CLA replacing VA and c9t11 CLA, respectively as predominate trans C18:1 and CLA isomers in fermenters. Additionally, t10 C18:1 replaced VA as the predominant trans C18:1 isomer in the rumen when high concentrate-low fiber diets were fed to cows (Loor et al., 2004) and steers (Sackmann et al., 2003). Relative to $t 10 \mathrm{C} 18: 1$, the increase in VA concentrations with oil supplements were more markedly with the high forage diet (foragexoil interaction, $\mathrm{p}<0.01$ ) possibly indicating more active $\mathrm{BH}$.

The effects of treatment diets on the DNA abundance of the selected ruminal bacteria are presented in Table 4. Dietary oil supplement had no effects $(p>0.05)$ on the DNA abundance of Anaerovibrio lipolytica and Butyrivibrio VAproducing bacteria at both forage levels. Potu et al. (2011) reported no effects for fish oil or soybean oil supplementation at $3 \%$ of diet DM on Anaerovibrio lipolytica. Feeding fish oil, sunflower oil or their combination to dairy sheep had no effect on the abundance of Butyrivibrio VA-producing bacteria (Belenguer et al., 2010). Maia et al. (2007) also reported no change in the growth of Anaerovibrio lipolytica upon incubating with PUFA at $50 \mu \mathrm{g} / \mathrm{ml}$; demonstrating the low sensitivity of Anaerovibrio lipolytica to oil supplements. The DNA abundances for Anaerovibrio lipolytica and Butyrivibrio VA-producing bacteria were significantly lower with the low forage diets suggesting that these bacteria are sensitive to low $\mathrm{pH}$ conditions. This is in agreement with Fuentes et al. (2009) who also reported similar decreases in the DNA abundance for Anaerovibrio lipolytica and Butyrivibrio VAproducing bacteria when fermenters $\mathrm{pH}$ was reduced from 6.4 to 5.6. Hobson (1965) and Henderson et al. (1969) also reported lower growth and lipase activity for Anaerovibrio lipolytica under low $\mathrm{pH}$ conditions. The decrease in Anaerovibrio lipolytica and Butyrivibrio VA-producing bacteria with low forage diets may, in part, explain the greater concentrations of $\mathrm{C} 18: 2 \mathrm{n} 6$ and $\mathrm{C} 18: 1 \mathrm{n} 9$ and the lower concentrations of BH end-products (trans C18:1 and C18:0) with the low forage diets relative to the high forage diets. Switching lactating dairy cows from a high to a low forage diet, which promotes low rumen $\mathrm{pH}$, resulted in lower levels of lipolytic activity and $\mathrm{BH}$ of unsaturated FA in ruminal fluid as measured by in vitro experiment (Van

Table 4..The effect of forage level and oil supplements on the DNA abundance (pg) of selected rumen bacteria at a given starting concentration

\begin{tabular}{|c|c|c|c|c|c|c|c|c|}
\hline \multirow{2}{*}{ Bacteria } & \multicolumn{4}{|c|}{ Treatment } & \multirow{2}{*}{ MSE } & \multicolumn{3}{|c|}{$\mathrm{p}$ value } \\
\hline & $\mathrm{HFC}^{\mathrm{a}}$ & $\mathrm{HFO}^{\mathrm{b}}$ & $\mathrm{LFC}^{\mathrm{c}}$ & $\mathrm{LFO}^{\mathrm{d}}$ & & Forage & Oil & Forage $\times$ oil \\
\hline Butyrivibrio SA, 18ng* & 14.93 & 13.61 & 12.34 & 15.82 & 1.105 & 0.87 & 0.36 & 0.07 \\
\hline Butyrivibrio VA, 18ng* & 0.33 & 0.29 & 0.01 & 0.01 & 0.044 & 0.01 & 0.77 & 0.72 \\
\hline Anaerovibrio lipolytica, 60 ng* & 1.67 & 2.6 & 0.05 & 0.09 & 0.449 & 0.01 & 0.32 & 0.36 \\
\hline
\end{tabular}

${ }^{\mathrm{a}}$ HFC = High forage control diet; alfalfa pellets at $700 \mathrm{~g} / \mathrm{kg}$ (diet DM) and no oil supplementation.

${ }^{\mathrm{b}} \mathrm{HFO}=$ High forage oil diet; control diet with $20 \mathrm{~g} / \mathrm{kg}$ (diet DM) soybean oil and $10 \mathrm{~g} / \mathrm{kg}$ (diet DM) fish oil.

${ }^{\mathrm{c}} \mathrm{LFC}=$ Low forage control diet; alfalfa pellets at $300 \mathrm{~g} / \mathrm{kg}$ (diet DM) and no oil supplementation.

${ }^{\mathrm{d}}$ LFO = Low forage oil diet; control diet with $20 \mathrm{~g} / \mathrm{kg}$ (diet DM) soybean oil and $10 \mathrm{~g} / \mathrm{kg}$ (diet DM) fish oil.

* Starting concentration. 
Nevel and Demeyer, 1996; AbuGhazaleh and Jacobson, 2007).

Interestingly, dietary oil supplement and forage level had no effects on the DNA abundance of Butyrivibrio SAproducing bacteria in spite of the decrease in C18:0 concentrations with oil supplementation and low forage diets (Table 3). Butyrivibrio SA-producing bacteria was identified to be the ruminal species responsible for the conversion of trans C18:1 into C18:0 (Paillard et al., 2007). The lack of significant effect of fish oil and low $\mathrm{pH}$ on Butyrivibrio SA-producing bacteria has been also reported by Belenguer et al. (2010) and Fuentes et al. (2009), respectively. Kim et al. (2008) and Huws et al. (2010) also reported that DNA abundance from the Butyrivibrio SAproducing group did not correlate with the C18:0 concentrations suggesting that Butyrivibrio SA-producing group may not indeed by the main C18:0 producer in the rumen. These results, therefore, would suggest that other, yet-uncultivated microbial species might be involved in C18:0 production and might fulfill a more important role in the final step of the $\mathrm{BH}$ process. Additionally, it's still also possible that oil supplement and low forage diets decreased the capacity of these bacteria to hydrogenate trans C18:1 rather than the bacteria as such. A recent study by Maia et al. (2010) reported that the inhibitory-growth effects of unsaturated FA on bacteria may be mediated via metabolic means rather than disruption of cell membrane.

\section{CONCLUSION}

The concentrations of VA and $c 9 t 11$ CLA were greater with the high forage diets while the concentrations of $t 10$ C18:1 and $t 10 c 12$ CLA were greater with the low forage diets and concentrations of these trans FA were further increased with oil supplementation. The lower concentrations of $\mathrm{BH}$ products (CLA, trans C18:1 and C18:0) seen with the low forage diets was in parallel with the lower DNA abundance for Butyrivibrio VA suggesting a role of these bacteria in trans FA formation particularly under high ruminal $\mathrm{pH}$ conditions. The nonresponsive effects of Butyrivibrio SA to oil supplementation and forage levels may indicate that these bacteria play a minor role in the production of C18:0 from trans C18:1.

\section{REFERENCES}

AbuGhazaleh, A. A. and B. N. Jacobson. 2007. Production of trans-C18:1 and conjugated linoleic acid production by ruminal microbes in continuous culture fermenters fed diets containing fish oil and sun flower oil with decreasing levels of forage. Animal 1:660-665.

AbuGhazaleh, A. A., S. Abo-El-Nor and S. A. Ibrahim. 2011. The effect of replacing corn with glycerol on ruminal bacteria in continuous culture fermenters. J. Anim. Physiol. Anim. Nutr.
95:313-319.

Alzahal, O., M. M. Or-Rashid, S. L. Greenwood, M. S. Douglas and B. W. McBride. 2009. The effect of dietary fiber level on milk fat concentration and fatty acid profile of cows fed diets containing low levels of polyunsaturated fatty acids. J. Dairy Sci. 92:1108-1116.

Amarù, D. L. and C. J. Field. 2009. Conjugated linoleic acid decreases MCF-7 human breast cancer cell growth and insulinlike growth factor-1 receptorl. Lipids 44:449-458.

Belenguer, A., P. G. Toral, P. Frutos and G. Hervas. 2010. Changes in the rumen bacterial community in response to sunflower oil and fish oil supplements in the diet of dairy sheep. J. Dairy Sci. 93:3275-3286.

Bhattacharya, A., J. Causey, G. Fernandes, J. Banu and M. Rahman. 2006. Biological effects of conjugated linoleic acids in health and disease. J. Nutr. Biochem. 17:789-810.

Choi, N. J., J. Y. Imm, S. Oh, B. C. Kim, H. J. Hwang and Y. J. Kim. 2005. Effect of $\mathrm{pH}$ and oxygen on conjugated linoleic acid (CLA) production by mixed rumen bacteria from cows fed high concentrate and high forage diets. Anim. Feed Sci. Technol. 123-124:643-653.

Doreau, M., G. Chesneau, F. Glasser, S. Laverroux and J. Normand. 2009. Effect of linseed fed as rolled seeds, extruded seeds or oil on fatty acid rumen metabolism and intestinal digestibility in cows. Lipids 44:53-62.

Duckett, S. K. and M. H. Gillis. 2010. Effects of oil source and fish oil addition on ruminal biohydrogenation of fatty acids and conjugated linoleic acid formation in beef steers fed finishing diets. J. Anim. Sci. 88:2684-2691.

Fuentes, M. C., S. Calsamiglia, P. W. Cardozo and B. Vlaeminc. 2009. Effect of pH and level of concentrate in the diet on the production of biohydrogenation intermediates in a dual-flow continuous culture. J. Dairy Sci. 92:4456-4466.

Harfoot, C. G. and G. Hazlewood. 1997. Lipid metabolism in the rumen. In: The rumen microbial ecosystem (Ed. P. N. Hobson and C. S. Stewart). Blackie and Prof., London, UK, pp. 382426.

Henderson, C., P. N. Hobson and R. Summers. 1969. The production of amylase, protease, and lipolytic enzymes by two species of anaerobic rumen bacteria. In Proc. 4th Int. Symp. Prague, Czechoslovakia: Continuous Culture Microorganisms, p. 189.

Hobson, P. N. 1965. Continuous culture of some anaerobic and facultatively anaerobic rumen bacteria. J. Gen. Microbiol. 38:167-180.

Huot, P. S. P., D. W. L. Ma and B. Sarkar. 2010. Conjugated linoleic acid alters caveolae phospholipid fatty acid composition and decreases caveolin-1 expression in MCF-7 breast cancer cells. Nutr. Res. 30:179-185.

Huws, S. A., M. R. F. Lee, S. M. Muetzel, M. B. Scott and R. J. Wallace. 2010. Forage type and fish oil causes shifts in rumen bacterial diversity. FEMS Microbiol. Ecol. 73:396-407.

Jiang, Z. Y., L. Yang, S. Q. Jiang, Y. C. Lin, W. J Zhong and C. T. Zheng. 2010. Conjugated linoleic acid differentially regulates fat deposition in backfat and longissimus muscle of finishing pigs. J. Anim. Sci. 88:694-1705.

Jin, G. L., Y. J. Kim, M. K. Song, S. H. Choi and H. G. Lee. 2008. Effects of monensin and fish oil on conjugated linoleic acid production by rumen microbes in Holstein cows fed diets 
supplemented with soybean oil and sodium bicarbonate. AsianAust. J. Anim. Sci. 21:1728-1735.

Kelley, N. S., K. L. Erickson and N. E. Hubbard. 2007. Conjugated linoleic acid isomers and cancer. J. Nutr. 137:2599-2607.

Kim, E. J., S. A. Huws, M. R. F. Lee, J. D. Wood, S. M. Muetzel and R. Wallace. 2008. Fish oil increases the duodenal flow of long chain polyunsaturated fatty acids and trans-11 18:1 and decreases 18:0 in steers via changes in the rumen bacterial community. J. Nutr. 138:889-896.

Kucuk, O., B. W. Hess and D. C. Rule. 2008. Fatty acid compositions of mixed ruminal microbes isolated from sheep supplemented with soybean oil. Res. Vet. Sci. 84:215-224.

Lee, M. R. F., K. J. Shingfield, J. K. S., Tweed, V. Toivonen, S. A. Huws and N. D. Scollan. 2008. Effect of fish oil on ruminal biohydrogenation of C18 unsaturated fatty acids in steers fed grass or red clover silages. Animal 2:1859-1869.

Loor, J. J., K. Ueda, A. Ferlay, Y. Chilliard and M. Doreau. 2004. Biohydrogenation, duodenal flow, and intestinal digestibility of trans fatty acids and conjugated linoleic acids in response to dietary forage:concentrate ratio and linseed oil in dairy cows. J. Dairy Sci. 87:2472-2485.

Maia, M. R., L. C. Chaudhary, L. Figueres and R. J. Wallace. 2007. Metabolism ofpolyunsaturated fatty acids and their toxicity to the microflora of the rumen. Antonie Van Leeuwenhoek 91:303-314.

Maia, M. R., L. C. Chaudhary and C. S. Bestwick. 2010. Toxicity of unsaturated fatty acids to biohydrogenating ruminal bacterium, Butyrivibrio fibrisolvens. BMC. Microbiol. 10:52.

Miranda J., I. Churruca, A. Fernández-Quintela, V. M. Rodríguez, M. T. Macarulla, E. Simón and M. P. Portillo. 2009. Weak effect of trans-10, cis-12-conjugated linoleic acid on body fat accumulation in adult hamsters. Br. J. Nutr. 102:1583-1589.
Paillard, D., N. McKain, L. C. Chaudhary, N. D. Walker, F. Pizette, I. Koppova, N. R. McEwan, J. Kopecny and P. E. Vercoe. 2007. Relation between phylogenetic position, lipid metabolism and butyrate production by different Butyrivibrio-like bacteria from the rumen. Antonie Van Leeuwenhoek 91:417-422.

Peterson, D. G., L. H. Baumgard and D. E. Bauman. 2002. Short communication: milk fat response to low doses of trans-10, cis-12 conjugated linoleic acid (CLA). J. Dairy Sci. 85:17641766.

Piperova, L. S., J. Sampugna, B. B. Teter, K. F. Kalscheur, M. P. Yurawecz, Y. Ku, K. M. Morehouse and R. A. Erdman. 2002. Duodenal and milk trans octadecenoic acid and conjugated linoleic acid (CLA) isomers indicate that postabsorptive synthesis is the predominant source of cis-9-containing CLA in lactating dairy cows. J. Nutr. 132:1235-1241.

Potu, R. B., A. A. AbuGhazaleh, D. Hastings, K. Jones and S. A. Ibrahim. 2011. The effect of lipid supplements on ruminal bacteria in continuous culture fermenters varies with the fatty acid composition. J. Microbiol. 49:216-223.

Sackmann, J. R., S. K. Duckett, M. H. Gillis, C. E. Realimi, A. H. Parks and R. B. Eggelston. 2003. Effects of forage and sunflower oil levels on ruminal biohydrogenation of fatty acids and conjugated linoleic acid formation in beef steers and finishing diets. J. Anim. Sci. 81:3174-3181.

Tajima, K., R. I. Aminov, T. Nagamine, H. Matsui, M. Nakamura and Y. Benno. 2001. Diet-dependent shifts in the bacterial population of the rumen revealed with real-time PCR. Appl. Environ. Microbiol. 67:2766-2774.

Van Nevel, C. J. and D. I. Demeyer. 1996. Influence of pH on lipolysis and biohydrogenation of soybean oil by rumen contents in vitro. Reprod. Nutr. Dev. 36:53-63.

Varadyova, Z., S. Kišidayova, P. Siroka and D. Jalč. 2007. Fatty acid profiles of rumen fluid from sheep fed diets supplemented with various oils and effect on the rumen ciliate population. Czech. J. Anim. Sci. 52:399-406. 